\title{
THE EFFECTS OF AGRICULTURAL COOPERATIVES ON LAND CONFLICTS, VIOLENCE, AND COMMUNITY TRUST: HOUSEHOLD-LEVEL EVIDENCE FROM BURUNDI
}

\section{TOPHER L. MCDOUgAL and LARS AlMQUiST}

Topher L. McDougal is Assistant Professor, Economic Development and Peacebuilding, Kroc School of Peace Studies, University of San Diego, and Research Affiliate, Centre on Conflict, Development, and Peacebuilding, Graduate Institute for International and Development Studies, Geneva, Switzerland. The corresponding author, he may be reached at tlm@sandiego.edu. Lars Almquist is Research Associate with a U.S. Department of Justice-funded research project on gangs and sex trafficking at the University of San Diego's Kroc School of Peace Studies. A graduate of the Kroc School's Master's degree program in Peace and Justice Studies, he may be reached at almquist.lars@gmail.com. The authors thank Isidore Nyongabo, Cindi Cassady, Paul Flamm, and two anonymous reviewers for their ideas and suggestions, as well as Bertrand Mizero for English-Kirundi translation services and Plant with Purpose for logistical support in Burundi.

\section{Abstract}

Facing a population growth rate of 3.2 percent and dwindling per capita land access, many rural communities in Burundi are experimenting with land cooperatives to collectivize risk, share information, reap economies of scale (if any), and build trust between association members. We use unique field data gathered by one author (Almquist) during a one-shot evaluation of a cooperative association operating in three villages in southern Burundi. We employ pseudo difference-in-differences logistic regression models to assess the effects of the cooperative on the (1) incidence of reported land conflicts between 2008 and 2011, (2) perceived community land inequality, (3) reported acceptability of land inequality, (4) violence toward acquaintances, (5) trust of colleagues, and (6) trust of neighbors. We find no evidence that cooperatives affect the incidence of land conflicts, but do find that residents of cooperative villages exhibit heightened perceptions of, and lower tolerance for, land inequalities; they are less likely to report violence toward acquaintances, but cooperative members are more likely to do so than nonmembers; and nonmember residents of active cooperative villages report less trust toward neighbors. We speculate that one weakness of cooperatives is that they may heighten the risk of violence between members and nonmembers.

$\mathrm{B}$ urundi is one of the mostly densely populated and highly agrarian countries in Africa. Access to scarce farmland has played a significant role in motivating the recurrent mass violence characterizing much of its postcolonial history. Neighboring Rwanda has countered similar issues with government pushes for knowledge-based economic growth and rural land redistribution. Burundi, by contrast, boasts no similar efforts, despite a 3.2 percent population growth rate that threatens to double the number of mouths to feed in 22 years and raises the likelihood of a relapse into violent conflict. Faced with dwindling per capita land access, many rural communities are experimenting with land cooperatives as a means to collectivize risk, share information, bargain collectively, and reap economies of scale (if any). Such cooperatives, usually requiring a single public or private large landowner to donate a parcel to the enterprise, may also serve to bring neighbors into contact in a cooperative endeavor, thereby building trust between association members. ${ }^{1}$

The study reported on here leverages a unique dataset gathered in 2011 by one of the authors (Almquist) in the course of a one-shot evaluation of a cooperative association called Plant with Purpose operating in three villages in southern Burundi. We employ pseudo difference-in-differences logistic and ordered logistic regression models to assess the effects of the cooperative on the (1) incidence of reported land conflicts between 2008 and 2011, (2) perceived community land inequality, (3) perceived acceptability of land inequality, (4) violence toward acquaintances, (5) trust of colleagues, and (6) trust of neighbors. We conclude by speculating that one weakness of cooperatives - in addition to the common criticism that they are short-term solutions to a long-term problem - is that they may heighten the risk of violent conflict between members and nonmembers.

The article is structured as follows. Section 1 provides an in-depth overview of Burundi's post-colonial history, paying particular attention to the fraught issue of land distribution. Section 2 discusses ongoing debates over whether and how land inequality causes conflict, literature pertaining specifically to such questions in Burundi and its neighbor, Rwanda, and introduces a small model of how cognitive dissonance could 
cause greater psychic discomfort among nonmembers of a cooperative than existed beforehand. Section 3 explains our pseudo difference-in-differences logistic and ordered logistic models. Section 4 provides the results of our models, and section 5 concludes with a discussion of policy implications.

\section{Land matters in Burundi's history}

Prior to the advent of European colonialism in the Great Lakes region of Africa, Burundi was a part of a jointly ruled territory known as Ruanda-Urundi. The populations were composed of various clan-based lineages in a predominantly agricultural and pastoral economy, with roughly eighty-five percent of the population classified as Hutu, and roughly fourteen percent Tutsi. The remaining minority was a pygmy people known as the Twa. What today have become more hardened ethnic lines of "Hutu" and "Tutsi" were in many ways sociopolitical and economic distinctions applied interchangeably to individual clan members. The terms were fluid, and were often applied to denote a particular status within a patron-client relationship, with the Hutu ordinarily occupying the subordinate position of the recipient, and the benefactor donning the role of Tutsi. This was the case even if the recipient was from the Tutsi lineage, or if the benefactor originated from a Hutu clan. Lines between the two groups were historically blurred, and notions of age-old historic grievances between Hutu and Tutsi cannot be substantiated in the precolonial ethno-historical record. ${ }^{2}$

The 1885 Berlin Conference and the ensuing "scramble for Africa" left Ruanda-Urundi first in the possession of Germany. After its defeat in world war one, colonial Belgium then acquired the territory. Interconnected clan lineages increasingly transformed with the growing colonial influence of European Catholic missionaries, who propagated the manipulative Hamitic hypothesis - which favored Tutsis - and facilitated the hardening of ethnic lines in their newly obtained territory. As Belgian settlers began to perish in droves from the threat of new diseases in the Great Lakes region, the colonial power began to construct a ruling framework that would facilitate the exploitation of local populations without suffering the risk of excessive death of its own citizens. By playing one group against another in the colonial territories, Belgium was able to exact resources and tribute from her colonial subjects from a safe distance back in Europe. The missionaries remained, devoted to the cause of Christianizing and civilizing the native populations. They thus became a liaison for the Belgians, and subsequently advocated strongly for a minority Tutsi aristocracy to rule the domestic affairs of the territory, while the Hutu peasantry - the significant majority of the population-were made to work the land. This socially constructed ethnic cleavage took root and persisted, even as
In a study of an agricultural cooperative effort spread across three villages in southern Burundi, we find no evidence that cooperatives affect the incidence of land conflicts, but do find that residents of cooperative villages tend to exhibit heightened perceptions of, and lower tolerance for, land inequalities. We find residents of cooperative towns less likely to report violence toward acquaintances, but that cooperative members are more likely to do so. And while cooperative members report greater trust in colleagues, residents of active cooperative towns tend to report less. We conclude by speculating that one weakness of cooperatives, in addition to the common criticism that they are short-term solutions to a long-term problem, is that they may heighten the risk of violent conflict between members and nonmembers.

colonial independence movements began to arise the world over. The Tutsi population gradually acquired majority control of the bureaucratic administration of the government, the domestic security forces, as well as the military apparatus, and Tutsis were represented in disproportionately large numbers in institutions of higher education. ${ }^{3}$

The crystallizing of hostile ethnic relations in Burundi was greatly facilitated by the Hutu revolution in Rwanda, which took place from 1959 through 1962, an event which facilitated Belgium's granting of independence to both Rwanda and Burundi in 1962. Burundi's ruling Tutsi elite then realized that the only way to prevent such outbursts of ethnic violence and revolution in their own country would be to retain control of the state at all costs. Subsequent authoritarian Tutsi rule encountered periodic Hutu uprisings and coup attempts in the wake of independence. These were met with brutally repressive responses, including what one scholar has labeled "the first recorded case of genocide in the Great Lakes Region of Africa" occurring at the hands of the government, in 1972. In roughly four months of violence that year, the Tutsi army and security forces killed more than 200,000 Hutus, and displaced hundreds of thousands more from their villages. More than a reprisal for armed Hutu extremism, the government's response was a premeditated attempt to eradicate any existing or potential Hutu competition for control of the government, indicated by the rounding up of Hutu schoolchildren to be slaughtered, an overt attempt to clear the way for multiple future generations of uncontested Tutsi rule. ${ }^{4}$

The genocide of 1972 undoubtedly shaped the trajectory of Burundi's future. Ethnic relations took on a violent, vengeful character. The most prominent Hutu leaders were killed or run out of the country, leaving the government, the army, the security forces, and the education system nearly homogeneously populated by Tutsis. Elite Tutsis had access to state employment and resources, while the Hutu population was excluded from those resources and the patronage links that 
accompanied them. The majority of the Hutu population was forced to work the land, resulting in a population disproportionally dependent upon subsistence farming for survival. This pattern led to a post-genocide period of relative law and order, with successive authoritarian governments maintaining a repressive peace by deploying armed security forces to crush dissent. However, unlike the genocide of 1972, an army-led coup in 1988, followed by brutally violent repressions that killed roughly 30,000 Hutus in northern Burundi, caught the attention of the world community. A combination of pressure from human rights advocacy groups, a wave of democratization movements across Africa, and multilateral international sanctions imposed on an already weak economy led the government to pursue the drafting of a democratic constitution in 1992, with a call for democratic multiparty elections to take place the following year. ${ }^{5}$

In a sweeping victory in July of 1993, Melchior Ndadaye, a Hutu candidate from the Front for Democracy in Burundi (FRODEBU), became the first civilian and democratically elected president in Burundi's history. Ndadaye's capture of a staggering 71 percent of the vote in internationally certified free and fair elections was mirrored later that month when FRODEBU captured 65 of the 81 seats in the national parliament. In a nation radically polarized between ethnic groups representing significantly disproportionate shares of the total population, the elections of 1993 portended more than just a political defeat for the ruling minority Tutsi cadres. In addition to fears of reprisal killings by newly empowered Hutus, the specter of losing control of valuable occupations in the government and the military — and the patronage links that radiated from them-was inconceivable. In a chronically underdeveloped country of subsistence farmers, where the average civil servant salary places that individual in the top six percent of income-earners, losing these links threatened dramatic economic and social decline. Thus, fears of both physical and economic threats to their survival motivated the Tutsi-dominated army to take matters into its own hands, whereupon they assassinated Ndadaye on 21 October 1993, barely four months after he was elected. ${ }^{6}$

Burundi's peaceful transition to democracy thus exploded into violent ethnic conflict, with Hutu rebel factions and the Tutsi-led army slaughtering civilians from rival ethnic groups in fighting that has been characterized as a "war of massacres." Over the course of the next fifteen years, the Burundian violence directly consumed nearly 300,000 lives, and displaced more than one-sixth of the total population, with a number far surpassing that figure perishing from illness and indirect effects of the war. Multiple rebel groups refrained from joining the peace talks resulting in the Arusha Agreement of 2000, leaving the parties at the table forced to sign "a peace accord without peace." The continued fighting left national infrastructure, the healthcare system, and the economy in ruins, with Burundian real per capita GDP dropping from US\$240 in 1986 to just US\$80 in 2002, and just one-third of the per capita rate at the time of independence forty years earlier. Moreover, while the country's economic performance has improved over the past half decade (by 2012, per capita income had risen to US\$240 again), Burundi remains one of the world's most underperforming economies. For instance, it lagged behind Sub-Saharan Africa over the 1970-2007 time period both in terms of economic growth (2.1 percent to SSA's 3.8 percent) and investment (10.8 percent of GDP to SSA's 21.3 percent). ${ }^{7}$

Burundi's post-independence history in many ways embodies a conflict trap, whereby violent conflict devastates an economy, destroying gains of development, and thereby perpetuating a vicious cycle of violent conflict. The United Nations has elected to intervene in Burundi in order to mitigate the likelihood that the country relapses into violent civil war yet again. Focusing specific attention on Burundi through the Peacebuilding Commission, established in 2006, the United Nations has pressed for democratic elections, the dissemination of democratic institutions, and a power-sharing agreement between ethnic groups in both the political and military apparatuses. However, aside from a few journalistic reports, international attention has largely ignored the potential for future violent conflict in Burundi, and particularly to shrinking access to land across the country. ${ }^{8}$

As a result of the generational cycles of violent conflict, hundreds of thousands of Burundians fled their homes. At the height of the most recent violence, more than one of every six inhabitants of Burundi was displaced either inside or outside of the country, with many individuals still waiting to repatriate after the genocide in 1972 . In addition to the nearly 400,000 refugees waiting to be repatriated into Burundian society in 2006 , the nation played host to more than 24,000 refugees from the Democratic Republic of Congo. With the notable exception of the work of Liisa H. Malkki, little research has been done on the disruption such displacement has rendered upon Burundian agrarian society, or to the relationships of the displaced. ${ }^{9}$

Burundians choosing to flee violence in their communities effectively forsook their livelihoods. With thousands of refugees from decades-old violent conflicts remaining outside of the country, there was little guarantee of the displaced recovering anything they left behind. As roughly 90 percent of Burundians make their living in the agricultural sector, the majority scraping by as subsistence farmers, there was virtually no way to take significant assets into exile. Those interviewed during the field-research often reported fleeing in the night 
with young children tied to their backs and a few nights' worth of food, thus leaving behind their houses, their farms, and their livestock. A large proportion of returnees interviewed reported having difficulties reclaiming their former houses and property. Virtually all reported that their livestock had either perished or were stolen during their sustained periods of displacement.

Acutely complicating the ability for returning Burundians to reclaim land and property forsaken during episodes of violent conflict was the adoption of the Burundian Land Code of 1986. After the 1972 genocide, the Tutsi government often sold Hutu land-holdings as patronage rewards. The Land Code of 1986 additionally provided that individuals holding receipts of purchase from the government would thereby legally own the land after fifteen years. Further, codified into national law were certain customary laws that allowed land abandoned for thirty years by its original owners to be claimed and legally possessed by those currently occupying it. Such provisions have greatly increased the difficulty for returnees attempting to reclaim land previously owned by themselves or their families. As paper titles and land deeds were virtually nonexistent in the 1970 s, it is necessary that land ownership be proven through the testimony of witnesses. Many witnesses are deceased or displaced, though, and thus such land reclamation has become even more difficult in contemporary Burundi. ${ }^{10}$

A surge of repatriating refugees, with little nonagricultural opportunity for survival, has placed immense pressure on existing land-holdings. Such pressure has led to a rapid rise in land-related conflicts, and the eruption of land-based violence among the general population. As there is virtually no middle or managerial class in Burundi, few off-farm employment opportunities exist, and prospering through agricultural employment and subsistence farming is perceived to be impossible. The resulting disillusionment may be exploited and channeled into support for coups or wider civil unrest. In the Burundian context, the state apparatus itself, along with the patronage links that radiate from it, has emerged as the most rewarding prize to be captured. In light of a post-colonial national history characterized by cycles of mass violence, the opportunity for an opposition movement to exploit land-related issues in order to cultivate civil unrest and to mobilize masses against the fragile democratic government is ripe.

\section{Land inequality and conflict}

Theory and evidence

Scholars have long debated the role of land inequality in precipitating violent conflict. A possible causal relationship between these two might operate directly or indirectly through its effect on economic growth. In the first instance, land inequalities may increase the expected gains to the poor from usurping the property of the rich. Christopher Cramer describes a wide variety of arguments for and against links between inequality and (violent) conflict, both linear and nonlinear in form. Nonlinear proponents include those who argue for U-shaped and inverted-U-shaped relationships between the two phenomena. In the U-shaped camp is Albert Hirschman, who describes a possible "tolerance for inequality" that makes some moderate degree of inequality optimal: Any higher and people would attempt to violently usurp the wealth of the rich; any lower and socioeconomic mobility would appear less possible. In the inverted U-shaped camp are those who argue that extreme inequality disenfranchises the losers to such an extent as to make effective violent redistribution impossible, and that radical equality reduces the incentive for violent usurpation of others' property. In the middle, then, a region for potential unrest exists. In terms of indirect relationships via the intervening variable of economic growth, some cross-country panel evidence suggests that land inequality negatively affects economic growth. ${ }^{11}$

In Burundi, unequal access to land has been empirically linked to the explosion and exacerbation of violent conflict in 1993, which thrust the nation into more than a dozen years of civil war. Further, the absence of consistent rainfall in Burundi, the presence of which is the lifeblood of economic survival for the country's subsistence farmers, has been linked to the increased recruitment of rebels associated with violent conflict. The inability of dispossessed subsistence farmers to procure enough productive land for themselves and their descendants has been proposed as a significant factor influencing the breathtaking speed and scope of the Rwandan genocide in 1994. Marijke Verpoorten similarly finds that high population density and low land access among young men are both highly predictive of local violence. However, she cautions that high density may not operate in the way predicted by Malthus, but rather either by making mass mobilization by violence entrepreneurs easier, or by providing an incentive for violence if lootable resources tend to be more ubiquitous in densely populated areas. Addressing the first alternative explanation, for instance, Omar McDoom argues that participation in Rwanda's genocide at the individual level was significantly determined by the number of other participants located nearby, postulating mobilization by social network. However, the population-density-as-social-mobilizer argument tends to beg the question of why violence is occurring in the first place. And the much-reviled ethnic grievance hypothesis seems problematic here, too: It has been shown, in both Burundi and Rwanda, that outbreaks of violence featured the killing of wealthier possessors of land and livestock by dispossessed members of their own ethnic group. ${ }^{12}$ 


\section{A model}

We hypothesize that, while Burundian cooperatives reduce vertical inequality by definition, they introduce the specter of horizontal inequality between two artificially created groups: members and nonmembers. We speculate that the mechanism that would drive this differentiation is akin to the social psychological theory of cognitive dissonance, which has found expression in the economic literature. According to this theory, psychic discomfort is experienced when two beliefs or cognitions contradict one another. In this case, villagers may wish to believe in a fundamental equality that underpins community cohesion. However, they also periodically come into contact with those who own or have access to considerably more land than they do, undermining their sense of community cohesion. If this cognitive dissonance is triggered each time someone sees a land-privileged individual, paradoxically, the chances of experiencing cognitive dissonance associated with land inequality rise as land inequality declines. The reason for this is that whereas previously just a small handful of landowners may have owned much land, now a considerable minority of the village enjoys relative asset wealth. ${ }^{13}$

Figure 1 illustrates this idea with Lorenz curves, where the $x$-axis is the number of up to 20 hypothetical villagers arranged by increasing land wealth, and the $y$-axis is cumulative land ownership. A land-Gini coefficient or ratio can be calculated by dividing the area between the line of a given scenario and that designating perfect equality by the area under the perfect equality line. The smaller the ratio, the lower the inequality. Each scenario applies to a 20 person village with a total of 20 hectares. In scenario $1-$ a village in which no cooperative is operational - one privileged person owns over half the land in the village ( 10.5 of the 20 hectares), and the remaining 19 villagers own $1 / 2$ hectare each (i.e., the remaining 9.5 hectares). In scenario 2-a village in which a cooperative is operational - half the villagers own $1 / 2$ hectare each $(5$ hectares in total), and the other half have access to 1.5 hectares per person (the remaining 15 hectares). Villagers 1 through 10 therefore find themselves with identical resources in the two scenarios. The land-Gini coefficient is lower, and inequality smaller, in scenario 2 than in scenario 1 . However, the random probability of a poor villager meeting a relatively rich villager in scenario 1 is just one in 19 ( or $\mathrm{P}=0.05$ ), while the probability of doing so in scenario 2 is 10 in $19(\mathrm{P}=0.53)$.

This intuition can be captured in a simple model. If we define the discomfort, $D$, of seeing a relatively rich person as a function of the relative inequality, $i$, and the share, $p$, of villagers, $V$, in the cooperative, then we might have something like:

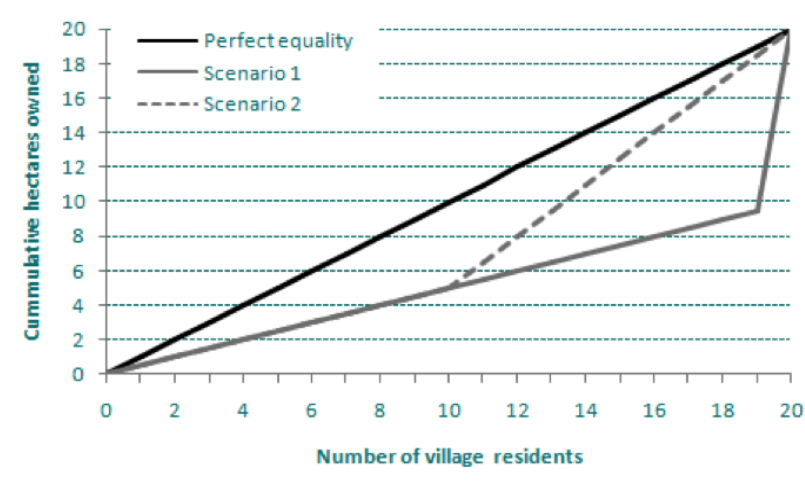

Figure 1: Lorenz-curves for two scenarios of land-inequality.

(1) $D=\left(\frac{p V}{V-1}\right) i=\left(\frac{p V}{V-1}\right)\left(\frac{L_{r}}{L_{p}}\right)^{\alpha}, 0<\alpha<1$,

where $L_{r}$ is the land access of each rich person, $L_{p}$ is that of each poor person, and $\alpha$ is a coefficient of intolerance for inequality. For instance, in equation (1), the smaller is $\alpha$ (tending toward 0 in the extreme), the more land inequality is tolerated and there would be little discomfort. Assuming a static amount of total available land, $L$, then $p$ and $i$ must be related, and so we state that

(2) $L_{r}=\frac{L-L_{p}(V-p V)}{p V}=\frac{L-L_{p} V(1-p)}{p V}$.

Substituting equation (2) into (1), we obtain each nonmember's level of discomfort as

(3) $D=\left(\frac{p V}{V-1}\right)\left(\frac{L-L_{p} V(1-p)}{p V L_{p}}\right)^{\alpha}$.

If we then multiply the individual discomfort, $D$, by the number of nonmembers, $V-p V$, we obtain the total collective discomfort manifested by nonmembers. Figure 2 shows that this model predicts that total discomfort among nonmembers will initially rise with the number of villagers being admitted to the cooperative. And although this discomfort continues to rise with the size of the cooperative at the individual level, the total amount of discomfort begins to diminish after some point because a more inclusive cooperative implies fewer nonmembers. Indeed, the point of maximum total discomfort shifts to the left as $\alpha \rightarrow 1$, and shifts toward the middle ( $p=0.5$ ) as $\alpha \rightarrow 0$. This model implies our central hypothesis, that the advent of a cooperative in a village will, even while reducing 
vertical inequality, increase horizontal inequality, undermining community cohesion between members by nonmembers.

\section{Empirical strategy}

A small number of agricultural cooperatives were organized by a rural development NGO called Plant with Purpose. A one-shot evaluation of these efforts as requested and specified by the NGO afforded an opportunity to collect the survey data we are here analyzing. We wish to test whether the implementation of the cooperative model in villages in rural Burundi did in fact have the predicted effect of undermining community cohesion between members by nonmembers. The latter is measured using a suite of six proxies: (1) reported land conflicts; (2) perception of inequality; (3) acceptance of inequality; (4) reports of violence toward oneself or one's acquaintances in the past year; (5) self-reported levels of trust among neighbors; and (6) self-reported levels of trust among colleagues.

The empirical strategy we employ imperfectly mimics a difference-in-differences (DiD) analysis on a cross-sectional dataset of 95 community members in three different villages in which the cooperative has been, or is becoming, operational. As such, we term our analysis a pseudo-DiD. In two communities, cooperatives have been operational for 3 years; in the third, a cooperative membership had just formed, but no harvests had yet been made. We interact a binary cooperative membership variable, $m$, with a binary time variable, $t$. The time variable takes a value of 0 for a community upon the inception of the local cooperative, and 1 for a community 3 years later. The treatment variable takes a value of 0 for nonmembers of the cooperative and 1 for members. The model is written in a straightforward way as

(4) $\operatorname{Pr}(y=1)=\lambda\left(\beta_{0}+\beta_{1} t+\delta_{0} m+\delta_{1} t m+\mu\right)$,

where $\lambda$ is the logit function, $y$ is the binary (or ordinal polychotomous) outcome variable, and $\mu$ the error term. In a standard DiD, $t$ captures aggregate factors that would cause changes in $y$ over the time period specified ( 3 years, in this case), and $m$ captures the possible differences between control and treatment groups. While DiD is most effectively employed when control and treatment are randomly assigned to individuals, there is the possibility for inherent selection biases here: Those farmers who choose to join the cooperative may on average exhibit higher or lower levels of the outcome variable relative to nonjoiners. For instance, a farmer who is willing to join a cooperative may already be more trusting of his or her neighbors than those who are unwilling to join. The variable $m$ will then play an important role in controlling for possible

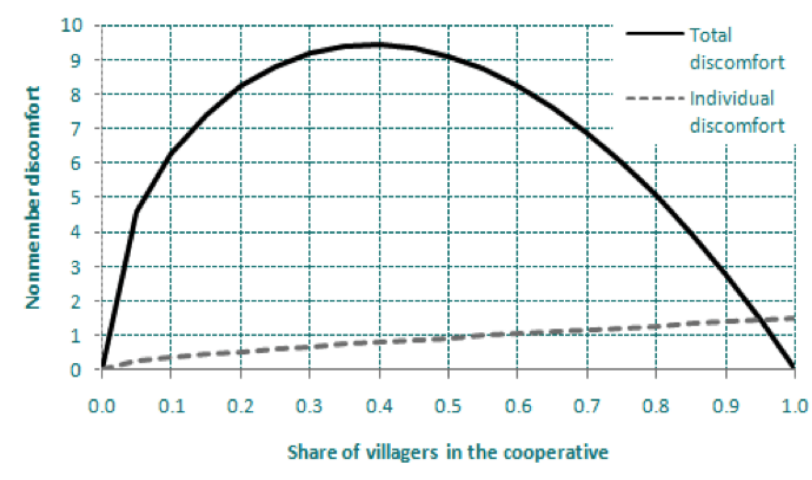

Figure 2: Individual and total nonmember discomfort as a function of rising cooperative membership as a share of village population. $V=20 ; L=20 ; L_{p}=0.5 ; \alpha=0.5$.

selection bias.

The DiD coefficient, $\delta_{1}$, pertains just to the binary interaction term, $t m$, which takes on a value of 1 only for those observations that are simultaneously cooperative members, and have been so for 3 years. The DiD estimate is then given by

$$
\begin{aligned}
\delta_{1}=\left[\operatorname{Pr}\left(\bar{y}_{m=1, t=1}\right)\right. & \left.-\operatorname{Pr}\left(\bar{y}_{m=1, t=0}\right)\right] \\
& -\left[\operatorname{Pr}\left(\bar{y}_{m=0, t=1}\right)-\operatorname{Pr}\left(\bar{y}_{m=0, t=0}\right)\right]
\end{aligned}
$$

However, the dataset we have used has one serious shortcoming that prevents us from making causal claims. The nature of the one-shot evaluation precluded the possibility of a pretest and post-test in the same communities, hence the term pseudo-DiD. As mentioned, the two communities with three years' experience hosting a cooperative are different from the one community where a cooperative is just starting. Therefore, while all communities are located in rural, southern Burundi, the outcome differences attributed to the passage of time may be driven by these community-level differences. This is a fundamental problem, and while we attempted to control for this statistically by using binary variables for the communities themselves (the coefficients for which were not statistically significant), the survey was administered in so few communities that such a strategy is only a very partial remedy. (We also controlled for individual-level characteristics that might have varied across communities, but such controls did not change our results.)

There are positive and negative aspects of the data from the perspective of reducing selection bias at the village level. On the one hand, all communities elected to start a local chapter of the land cooperative. This fact implies that in all communities, there was local support for the idea, and that there was a local 
landowner who was willing to donate land to the enterprise. On the other hand, two of the three communities were early adopters, and one elected to start a cooperative chapter only three years later. This may have been due solely to the organization's capacity to expand across villages, or it may reflect a difference in community preferences. In the spirit of transparency, we describe below each community and its idiosyncratic history and involvement in the cooperative, and we realize that such idiosyncrasies represent a serious caveat in the interpretation of our results.

\section{Muzye, Rutana}

Muzye represents the most dynamic community in which Almquist conducted research in the summer of 2011. Located less than a dozen kilometers from the Tanzanian border, Muzye is a patchwork of repatriated refugees, inhabitants who never left the country, demobilized former combatants, and those who fled to the bush during conflict but never left the country. Access to water is difficult during the dry season, and adequate healthcare is challenging to procure. Additionally, one-third of farmers' association members who reported fleeing their homes because of violence fled to Tanzania, while a larger proportion - one-half - of the nonmembers who reported fleeing from violence left the country. Unexpectedly, tensions between men and women were higher in this community than the other two, with accusations of polygamy and domestic violence surfacing in many interviews. While such a relational environment remained challenging for many women interviewed, Muzye's hosting of a substantial rural marketplace appeared to provide opportunities for many women that were not present in either Kiremba or Musongati (discussed below): In order to supplement their subsistence farming incomes, a number of women engaged in various small business enterprises. Often purchasing foodstuffs, such as beans or maize, on credit, women would then sell those goods in the market, bringing the profit home to their families. Although the explanation is unclear, some women reported successful business tenures, while others reported that their businesses soon went bankrupt.

The first association formed by Plant With Purpose in Burundi, the Muzye cooperative, had existed for three years at the time interviews were conducted. Twenty-five individuals constituted this association, with twenty present and available for interviews. Membership was originally opened to those able and willing to pay a 500-franc initial fee (roughly US\$0.40); nonetheless, membership was capped at twenty-five individuals. The association leadership structure included a president, vice president, treasurer, secretary, two advisors and two operations officers. The association meets monthly to discuss association business and holds periodic democratic elections to select its leadership. In addition to farming their own land, members commit to working on the association's land three to four days per week. Cassava is the main crop under cultivation and is farmed on land donated free of charge by the provincial government of Rutana. An additional single hectare of bananas is farmed on private land contributed by one of the members of the association. In order to sustain the association, the cooperatively farmed cassava is sold at the market, with a portion of the proceeds re-invested into the association for the subsequent planting and harvest season. Each association member received an additional share of the proceeds, valued at 50,000 Burundian francs per member (roughly US\$40) for the most recent cassava harvest (in early 2011), in addition to individual cassava cuttings both for individual and family consumption, as well as for planting and future harvest on the member's own land.

\section{Musongati, Rutana}

Located further away from the Tanzanian border, in northwest Rutana, the farmers' association in Musongati has forty-two members and works six hectares of land donated by a family, three of whom are members in the association. The association has partnered with Plant With Purpose for three years, and farms cassava and arrowroots. Leadership also consisted of a president (who was also a member of the land-owning family), vice president, treasurer, secretary and advisors. Members of the Musongati association had the least secure access to water of the three communities, with the vast majority of members walking more than one kilometer to retrieve water from a communal pipe stemming out of a mountain or retrieving their water from a stream, rather than a well or a faucet as in Kiremba and Muzye. Families of many members in Musongati were routinely ravaged by malaria, diarrhea, and other illnesses. Interviewees in Musongati reported the lowest level of land quality, the most prominent reporting of food insecurity, and the highest ratio of active land conflicts. Additionally, every single interviewee in Musongati reported having fled their home due to violence during their lifetime, with the vast majority remaining in the country. Due to lower than expected yields and high food insecurity, the Musongati association's harvest was not sold for a profit; however, the harvest was divided evenly between the members and the wider community in desperate need of food.

\section{Kiremba, Bururi}

The province of Bururi in southern Burundi has featured prominently in the country's post-independence history. Three consecutive Tutsi presidents arose from a single commune 
within the province, Rutovu, to rule Burundi for nearly three consecutive, repressive decades, a period running from 1966 through Burundi's first democratic elections in 1993. After the outbreak of civil war at the end of 1993, the last of the three presidents, Pierre Buyoya, assumed the presidency in a coup d'état, ruling in the midst of the civil war from 1996 through 2003. Owing in large part to this legacy of military and political rulers stemming from the province, and the patronage links that stemmed from it, the population in Kiremba, while remaining poor by any international standard, was considerably more privileged and stable than the other communities surveyed. Government investment in infrastructure projects brought running water to virtually the entire colline (an administrative unit just below commune), with all but one interviewee having access to a water faucet in their own backyard or that of a neighbor. Efficient access to water made hygiene easier, and lessened the amount of time spent gathering water from other sources, thus freeing up more time for individuals to cultivate land or attend school. Additionally, distance to a healthcare facility was exceptionally close, roughly ten minutes away, and a cooler annual temperature and climate reduced, but did not eliminate, the reported malaria prevalence rate throughout the community.

The population of Kiremba had little extended exposure to the effects of the civil war, with the main exception being an attack on a nearby private secondary school for boys by the rebel CNDD-FDD forces in the fall of 1997. More than forty students and faculty were killed in the nighttime raid, compelling much of the surrounding population to flee to the bush or to the neighboring provincial capital for days or weeks at a time. Relatively few members of the Kiremba community had experience fleeing to Tanzania, and additionally had little exposure to returnees repatriating from outside the country.

The farmers' association in Kiremba was in its incipient phase at the time of the interviews. The association consists of eighteen members. However, five were unavailable for the interviews during the field research in the province. Association leadership consisted of an elected president, vice president, treasurer, and secretary, with an additional member serving in an advisory role. The association predominantly cultivates potatoes on a one-hectare plot of land rented for 50,000 francs per year (roughly US\$40) from a member of the association. At the time of the interviews, none of the crop had as yet been harvested, and thus there was no income generated by the association.

\section{Results}

Table 1 gives results of uncontrolled logistic regressions for the six outcome variables of interest. Note that whether one is a member of the cooperative or not is not a significant predictor of any outcome. The fact of being a town that has hosted the cooperative for three years is statistically positively related to perception of land inequalities, and negatively related to the acceptance of those same inequalities. It also correlates negatively and statistically significantly with reported violence to oneself or one's acquaintances, and with levels of trust in one's colleagues. Finally, the fact of being a member of a cooperative in a town that has three years of experience hosting the cooperative is positively and statistically significantly correlated with a likelihood of reported violence against oneself or one's acquaintances, as well as the level of trust in one's colleagues.

Given the relatively small sample size, $N$-and more specifically, the small number of success cases as a subset of $N$ - the acceptable number of control variables that may be included in any given regression hovers only at around 1 . The land conflict variable, for instance, cannot, strictly speaking, support any further control variables at all without risking over-specification, while the violence against self or acquaintances variable can support one to two. Nevertheless, we included individual-level control variables on a singleton basis: Age, sex, land donor (i.e., whether the respondent was the original landowner who had donated his land to the collective), and cooperative leadership role (i.e., whether the respondent was a member of the cooperative leadership committee, which included posts for president, vice-president, secretary, and treasurer). We also ran fixed-effects regressions with a village-level dummy-variable distinguishing between the two treatment villages. In no case did the sign of the coefficients displayed in Table 1 change, coefficients that had been statistically significant at the $95 \%$ level universally remained so, and their magnitudes all stayed within 25 percent of the uncontrolled estimates. Moreover, the pseudo-R2 estimates decreased in all cases (see Table 2, which includes all controls). We therefore opted to perform our post-estimation analyses based solely on the uncontrolled models.

Figure 3(A) illustrates that residents of cooperative villages report generally higher perceptions of inequality than villages where cooperatives are nonoperational. Moreover, cooperative members and nonmembers were statistically indistinguishable from one another in the village where the cooperative was nonoperational, whereas the mean probability of reporting a high perception of inequality among noncooperative members exceeded the $95 \%$ confidence interval of the same statistic for nonmembers (the difference in slope is not statistically significant). Figure 3(B) illustrates that cooperative members and nonmembers are statistically indistinguishable in terms of their likelihood of having a high tolerance for inequality in the 
Table 1: Logistic models of the six outcome variables

\begin{tabular}{|c|c|c|c|c|c|c|}
\hline & (1) & (2) & (3) & (4) & (5) & $(6)$ \\
\hline Variables & $\begin{array}{l}\text { Land } \\
\text { conflict }\end{array}$ & $\begin{array}{l}\text { Perception } \\
\text { of inequality }\end{array}$ & $\begin{array}{l}\text { Acceptance } \\
\text { of inequality }\end{array}$ & $\begin{array}{l}\text { Violence toward } \\
\text { self/acquaintances }\end{array}$ & $\begin{array}{l}\text { Trust of } \\
\text { colleagues }\end{array}$ & $\begin{array}{l}\text { Trust of } \\
\text { neighbors }\end{array}$ \\
\hline Member & $\begin{array}{l}-0.272 \\
(1.049)\end{array}$ & $\begin{array}{l}-0.182 \\
(0.808)\end{array}$ & $\begin{array}{l}-0.405 \\
(1.017)\end{array}$ & $\begin{array}{l}-0.288 \\
(0.898)\end{array}$ & $\begin{array}{l}-0.944 \\
(0.868)\end{array}$ & $\begin{array}{l}-0.288 \\
(0.898)\end{array}$ \\
\hline Coop village & $\begin{array}{l}-0.182 \\
(0.849)\end{array}$ & $\begin{array}{l}\mathbf{2 . 6 5 9} * * \\
(1.180)\end{array}$ & $\begin{array}{l}-\mathbf{1 . 7 0 5 *} \\
(0.889)\end{array}$ & $\begin{array}{l}-2.197 * * * \\
(0.843)\end{array}$ & $\begin{array}{l}-0.405 \\
(0.812)\end{array}$ & $\begin{array}{l}0.348 \\
(0.868)\end{array}$ \\
\hline $\begin{array}{l}\text { Member * } \\
\text { coop village }\end{array}$ & $\begin{array}{l}0.834 \\
(1.206)\end{array}$ & $\begin{array}{l}-1.022 \\
(1.367)\end{array}$ & $\begin{array}{l}1.319 \\
(1.149)\end{array}$ & $\begin{array}{l}2.019 * \\
(1.078)\end{array}$ & $\begin{array}{l}2.672 * * \\
(1.114)\end{array}$ & $\begin{array}{l}0.202 \\
(1.114)\end{array}$ \\
\hline Constant & $\begin{array}{l}-0.981 \\
(0.677)\end{array}$ & $\begin{array}{l}0.336 \\
(0.586)\end{array}$ & $\begin{array}{l}1.609 * * \\
(0.775)\end{array}$ & $\begin{array}{l}1.099 * \\
(0.667)\end{array}$ & $\begin{array}{l}1.099 * \\
(0.667)\end{array}$ & $\begin{array}{l}1.099 * \\
(0.667)\end{array}$ \\
\hline Observations & 89 & 95 & 95 & 94 & 95 & 95 \\
\hline Log likelihood & -53.94 & -41.24 & -57.14 & -57.65 & -42.94 & -49.79 \\
\hline Chi2 & 1.360 & 12.60 & 5.705 & 12.28 & 11.90 & 0.781 \\
\hline Prob $>$ Chi2 & 0.715 & 0.00559 & 0.127 & 0.00650 & 0.00773 & 0.854 \\
\hline Pseudo R-squared & 0.0125 & 0.133 & 0.0475 & 0.0962 & 0.122 & 0.00779 \\
\hline
\end{tabular}

Notes: Standard errors in parentheses. $* * * \mathrm{p}<0.01, * * \mathrm{p}<0.05, * \mathrm{p}<0.10$.

Table 2: Controlled mixed-effects logistic models of the six outcome variables

\begin{tabular}{|c|c|c|c|c|c|c|}
\hline & (1) & (2) & (3) & (4) & (5) & (6) \\
\hline Variables & $\begin{array}{l}\text { Land } \\
\text { conflict }\end{array}$ & $\begin{array}{l}\text { Perception } \\
\text { of inequality }\end{array}$ & $\begin{array}{l}\text { Acceptance } \\
\text { of inequality }\end{array}$ & $\begin{array}{l}\text { Violence toward } \\
\text { self/acquaintances }\end{array}$ & $\begin{array}{l}\text { Trust of } \\
\text { colleagues }\end{array}$ & $\begin{array}{l}\text { Trust of } \\
\text { neighbors }\end{array}$ \\
\hline Member & $\begin{array}{l}-0.123 \\
(1.102)\end{array}$ & $\begin{array}{l}0.480 \\
(0.987)\end{array}$ & $\begin{array}{l}-0.105 \\
(1.102)\end{array}$ & $\begin{array}{l}-0.412 \\
(0.937)\end{array}$ & $\begin{array}{l}-1.314 \\
(0.967)\end{array}$ & $\begin{array}{l}-0.243 \\
(0.980)\end{array}$ \\
\hline Coop village & $\begin{array}{l}1.018 \\
(1.323)\end{array}$ & $\begin{array}{l}\mathbf{2 . 7 0 5} * * \\
(1.274)\end{array}$ & $\begin{array}{l}\mathbf{- 2 . 0 7 3 * *} \\
(0.948)\end{array}$ & $\begin{array}{l}\mathbf{- 2 . 1 4 0 * *} \\
(0.861)\end{array}$ & $\begin{array}{l}-0.787 \\
(0.870)\end{array}$ & $\begin{array}{l}0.465 \\
(0.939)\end{array}$ \\
\hline $\begin{array}{l}\text { Member * } \\
\text { coop village }\end{array}$ & $\begin{array}{l}-0.0247 \\
(1.440)\end{array}$ & $\begin{array}{l}-1.583 \\
(1.489)\end{array}$ & $\begin{array}{l}1.342 \\
(1.225)\end{array}$ & $\begin{array}{l}\mathbf{2 . 0 1 9 *} \\
(1.108)\end{array}$ & $\begin{array}{l}3.049 * * \\
(1.208)\end{array}$ & $\begin{array}{l}-0.186 \\
(1.190)\end{array}$ \\
\hline Age & $\begin{array}{l}0.00767 \\
(0.0172)\end{array}$ & $\begin{array}{l}\mathbf{0 . 0 5 8 8} * * \\
(0.0275)\end{array}$ & $\begin{array}{l}0.00914 \\
(0.0190)\end{array}$ & $\begin{array}{l}-0.00331 \\
(0.0162)\end{array}$ & $\begin{array}{l}0.00127 \\
(0.0193)\end{array}$ & $\begin{array}{l}\mathbf{0 . 0 4 4 3 *} \\
(0.0227)\end{array}$ \\
\hline Female & $\begin{array}{l}-0.585 \\
(0.534)\end{array}$ & $\begin{array}{l}1.227 * \\
(0.634)\end{array}$ & $\begin{array}{l}1.100 * * \\
(0.544)\end{array}$ & $\begin{array}{l}-0.410 \\
(0.500)\end{array}$ & $\begin{array}{l}1.239 * * \\
(0.597)\end{array}$ & $\begin{array}{l}0.323 \\
(0.580)\end{array}$ \\
\hline Landowner & $\begin{array}{l}0.000310 \\
(1.321)\end{array}$ & $\begin{array}{l}-0.598 \\
(1.457)\end{array}$ & $\begin{array}{l}17.01 \\
(5,783)\end{array}$ & $\begin{array}{l}0.00687 \\
(1.284)\end{array}$ & $\begin{array}{l}18.04 \\
(5,715)\end{array}$ & $\begin{array}{l}17.71 \\
(0)\end{array}$ \\
\hline Lead & $\begin{array}{l}-0.640 \\
(0.958)\end{array}$ & $\begin{array}{l}-1.219 \\
(0.866)\end{array}$ & $\begin{array}{l}-1.259 * \\
(0.737)\end{array}$ & $\begin{array}{l}0.361 \\
(0.759)\end{array}$ & $\begin{array}{l}0.497 \\
(1.029)\end{array}$ & $\begin{array}{l}0.281 \\
(0.893)\end{array}$ \\
\hline Constant & $\begin{array}{l}-1.527 \\
(1.249)\end{array}$ & $\begin{array}{l}\mathbf{- 2 . 4 0 5 * *} \\
(1.225)\end{array}$ & $\begin{array}{l}0.830 \\
(1.075)\end{array}$ & $\begin{array}{l}1.453 \\
(1.021)\end{array}$ & $\begin{array}{l}0.528 \\
(1.034)\end{array}$ & $\begin{array}{l}-0.643 \\
(1.057)\end{array}$ \\
\hline Constant 2 & $\begin{array}{l}0.356 \\
(0.679)\end{array}$ & $\begin{array}{l}0 \\
(0)\end{array}$ & $\begin{array}{l}0 \\
(0)\end{array}$ & $\begin{array}{l}0 \\
(0)\end{array}$ & $\begin{array}{l}0 \\
(0)\end{array}$ & $\begin{array}{l}0 \\
(0)\end{array}$ \\
\hline Observations & 88 & 93 & 93 & 92 & 93 & 93 \\
\hline Number of groups & 2 & 2 & 2 & 2 & 2 & 2 \\
\hline Log likelihood & -51.14 & -35.16 & -50.51 & -56.26 & -39.67 & -45.84 \\
\hline Chi2 & 3.393 & 17.06 & 11.31 & 10.98 & 12.52 & . \\
\hline Prob $>$ Chi2 & 0.846 & 0.0170 & 0.126 & 0.139 & 0.0846 & . \\
\hline Pseudo R2 & 0.00737 & -0 & $6.99 \mathrm{e}-09$ & 0 & $9.37 \mathrm{e}-09$ & $6.38 \mathrm{e}-09$ \\
\hline
\end{tabular}

Notes: Standard errors in parentheses. $* * * \mathrm{p}<0.01, * * \mathrm{p}<0.05, * \mathrm{p}<0.10$.

village in which the cooperative is not yet operational. In those where it is, however, the likelihood of a high inequality tolerance drops among nonmembers (although the difference in slope is, again, not statistically significant). Figure 3(C) illustrates that members and nonmembers of the cooperative are statistically indistinguishable in terms of reported violence against self or acquaintances in the village in which the cooperative is not yet operational. However, the likelihood of 


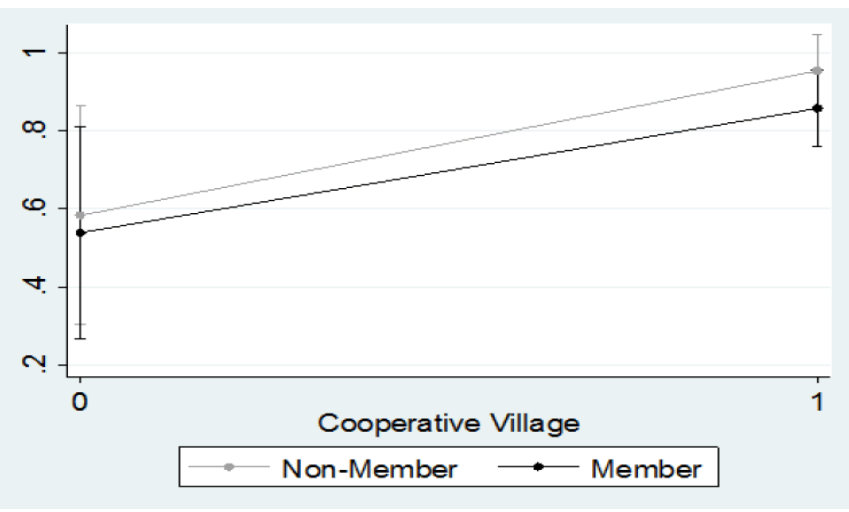

Figure 3(A): Adjusted predictions of the probabilities of high perception of inequality among cooperative members and nonmembers.

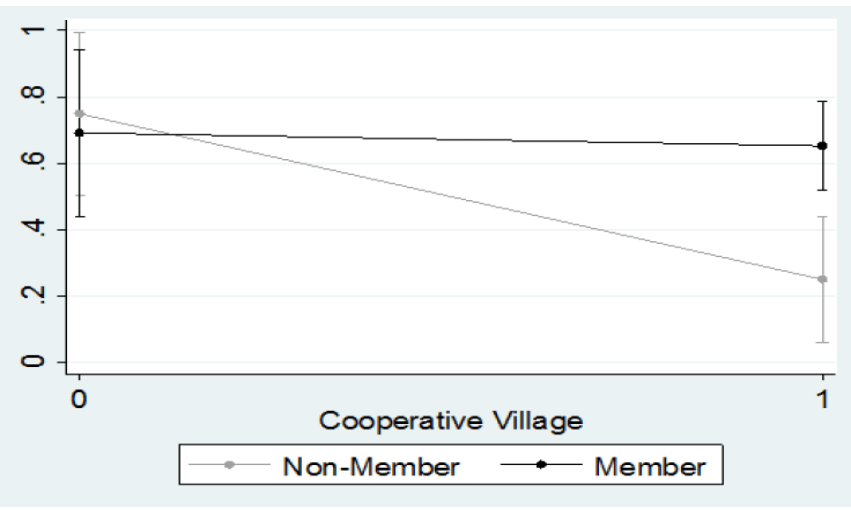

Figure 3(C): Adjusted predictions of violence reported against one's self or acquaintences.

reported violence against nonmembers in the villages where the cooperative is operational drops dramatically from around 75 percent to around 25 percent. At the same time, the likelihood of reported violence against cooperative members' self or acquaintances remains at roughly the same level, making for a statistically significant difference in slope. Finally, Figure 3(D) illustrates that members and nonmembers of cooperatives are statistically indistinguishable with regard to trust in their colleagues in the village in which the cooperative is not yet operational. However, in the villages where the cooperative has been operational, members' probability of reporting great trust in their colleagues exceeds that of nonmembers (and that of members in the village with a nonoperational cooperative), and again the difference in slopes is statistically significant.

In sum, nonmembers of cooperatives are more likely (although not statistically significantly so) to perceive inequality, and less likely (although again not significantly so) to tolerate inequality than members. Moreover, members are significantly more likely to have experienced violence against

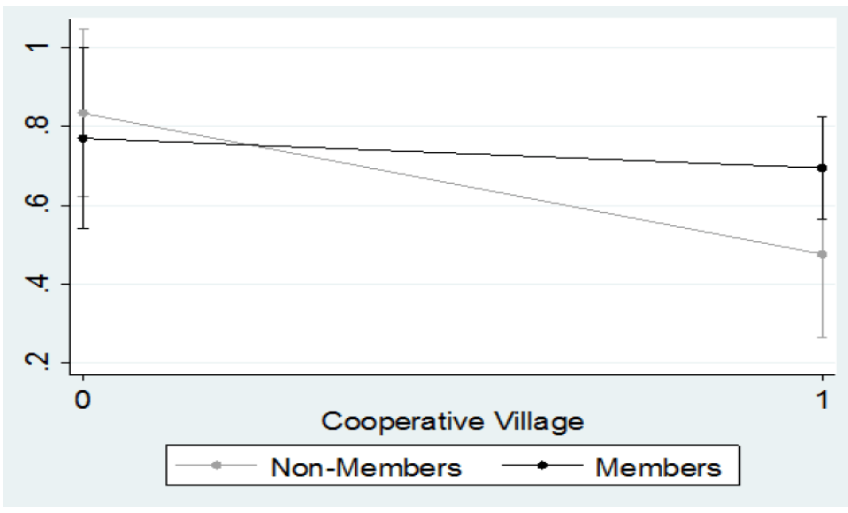

Figure 3(B): Adjusted predictions of the probabilities of high acceptance of inequality among cooperative members and nonmembers.

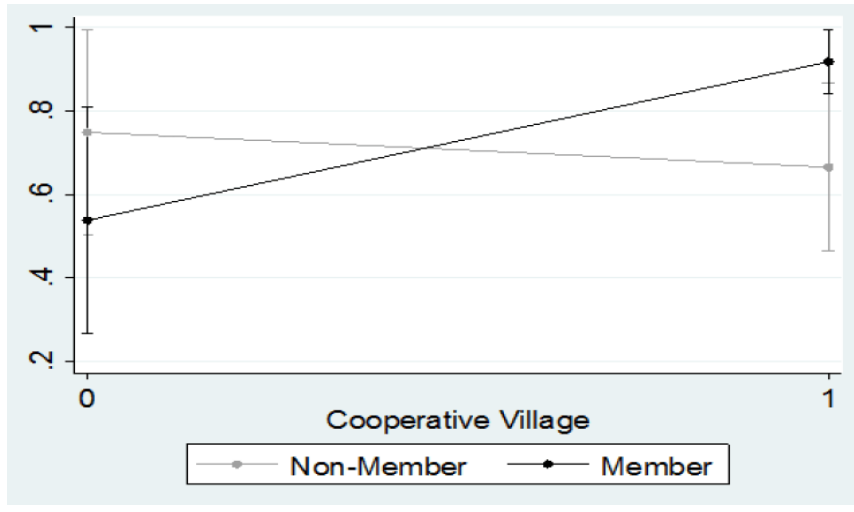

Figure 3(D): Adjusted predictions of high trust in colleagues.

self or acquaintances in the past year (even though violence is generally lower in cooperative-operational villages than in nonoperational ones), and more likely to develop trust in their colleagues than nonmembers.

\section{Discussion}

The general portrait painted above is, speculatively, one of group differentiation and divergence between members and nonmembers of the cooperative. While the incidence of land conflicts and the probability of high trust in one's neighbors seems to be unaffected by the operations of the cooperative, the other four outcomes may be. (And there is no reason that legal conflicts over land should necessarily increase in cooperative villages, as the cooperative does not imply land claims on properties not already owned by the original donating landowner or participating cooperative members.) Nonmembers of the cooperative may be growing more acutely aware of land inequality even as they grow less tolerant of it in the wake of a cooperative's operations. It may even be that 
nonmembers are directing violence more explicitly toward members, and that cooperative members' trust is turning inward toward each other. For instance, just prior to the administration of this survey, a hand grenade had been rolled into the hut of a local landowner in one of the study villages, killing him and his family at a cost of less than US\$1. So even while violence in the cooperative villages seems reduced, as compared to the controls, the distribution of violence seems increasingly concentrated on those privileged enough to be in the cooperative. Nor is it likely that nonmembers are indifferent to the gains of members: During the interviews, nonmembers almost without exception expressed a desire to join the cooperative.

Qualitative data from the interviews supports this reading of the data. Association membership seemed to be a status symbol, while members' gains from the cooperatives seemed to feed a growing sense of inequality. Cooperative members openly and overwhelmingly attributed recent livelihood improvements to association membership. Examples of narrative refrains that ran through each of the three cooperatives profiled include: "I am a member of the association and may not struggle to get money for school fees; I may have revenue to buy something of my own," and "When you are in such associations, you are able to produce more than by yourself, and it will improve your quality of life." Yet, many nonmembers, when asked to rate their quality of life with respect to that of their neighbors cited the gains of others as examples of their own lower quality of life. Nonmembers pointed to those who had upgraded the roofs of their houses from grass to tin and those who were able to purchase livestock as indicators that their own quality of life was below that of their asset-accumulating neighbors. Increased stockpiles of food and larger land-holdings were further cited as examples of inequality, as was a periodic lament that those with salaried, off-farm jobs had a perceived luxury of paying to join a cooperative as an auxiliary source of income, rather than as the only option for survival. Asked about their dreams for the future, nonmembers consistently expressed a desire to join a cooperative association so they could improve their own lives and that of their families. One woman bemoaned the recent selling of her land in order to pay for her own hospitalization after she simultaneously contracted malaria and typhoid. Reflecting on the drastic action she and her family had to undertake in order to save her life she remarked, "I was very, very sad to sell my land. Maybe if I was a member of an association, they would have helped me instead of me having been forced to sell my land." The outstanding debt for which she sacrificed her most precious asset, her land (which the majority of women are not privileged to own), proved to be

\section{9,000 francs, roughly US\$70.}

The theory of intra-communal differentiation and the proposed mechanism of cognitive dissonance are speculative. It bears repeating that the one-shot evaluation model prevents this study from making causal claims, despite our efforts to mimic a difference-in-differences methodology. Future studies of the social effect of cooperatives might not just add a longitudinal element to their study design, but also consider examining violence as a function of group membership via dyadic and directional social networks. ${ }^{14}$ While the ideas herein presented were supported by complementary qualitative methods (in-depth interviews and focus group discussions), those, too, suffer from the cross-sectional nature of the data. Future research might usefully employ ethnographic methods to obtain insights on interpersonal dynamics over time.

The typical criticism of the use of land cooperatives in Burundi to stave off a Malthusian trap and another possible genocide, is that they fail to dramatically increase productivity. They rarely involve mechanization, and what economies of scale they bring may be largely due to a greater division of labor. It has been suggested that, at best, cooperatives postpone a looming livelihoods crisis, buying the government a few more years to figure out a long-term solution that would relieve some of the pressure on rural lands. (The same criticism has also been leveled against the Burundi government's 2010 move to decentralize the state apparatus for land conflict arbitration to the local level. ${ }^{15}$ )

This study suggests yet another caveat of agricultural cooperatives. Most evaluations of cooperatives focus on the gains (in education, productivity, and collective bargaining) of members. They may not fully appreciate the ways in which such cooperatives may change social relations in villages where they are in operation. Such questions of who is "in" and who is "out" seem likely to take on greater salience in the context of Tanzania's President Jakata Kilwete ordering 35,000 "irregular migrants" from Burundi and Rwanda out of the country. With 15,000 Burundian nationals already on their way back to their country as of this writing (early 2014), many having lived years if not decades abroad, the pressure on the already-scarce commodity of land can only grow. ${ }^{16}$

How generalizable is this study to other countries or types of cooperatives? We urge caution when judging its external validity. Burundi's rather unique demographic and economic conditions mean that only a small proportion of the rapidly growing rural population is able to find urban work. With stagnant per capita incomes relative to the Sub-Saharan African and low-income countries generally, low-technology subsistence agriculture remains a mainstay of most rural livelihoods. The intra-communal differentiation we describe 
between members and nonmembers of agricultural cooperatives may therefore be an outgrowth of a country-specific, zero-sum game mentality toward agricultural lands. Even in Rwanda, although similar to Burundi in ethnic composition, geography, and history of land-driven violent conflict, subsistence land cooperatives may not have the same effect on local villages: Rwanda has a much higher urbanization rate, a rate of GDP growth twice that of Burundi, and a government promoting the country's role in the global knowledge economy. Moreover, other types of cooperatives may not entail similar dynamics, either. Cooperatives based on the processing of agricultural products, for instance, tend to cater to export markets, and therefore bring with them the possibility of enlarging the proverbial economic pie at the local level. While they may boost village-level productivity somewhat, subsistence cooperatives likely boast fewer forward and backward linkages to nonmembers than export-oriented cooperatives.

Some tentative policy implications stemming from the research reported in this article may be drawn out. First, the possible negative side-effects of agricultural cooperatives discussed here may be reduced if the village is small enough to allow the cooperative to extend membership to all community farmers. Second, to the extent that some villages will necessarily exceed the size at which that idea is feasible, making the boundaries between members and nonmembers fluid could help to reduce the ossification of group identities. For instance, if the cooperative were to grow at some sustainable rate per year, offering new memberships to the remaining community members, resentment might be tempered with the hope of livelihood betterment. The cooperative might not just grow in scale, but also in scope, involving erstwhile nonmembers in upstream and downstream value-added processes. Recalcitrant or unwilling cooperative members might also be disinvited. Cooperatives might themselves embark on educational outreach programs, helping nonmembers to acquire the knowledge and skills that members are cultivating within the organization. Each of these suggestions might serve to dissolve somewhat the in-group / out-group distinction.

\section{Notes}

1. Population growth rate: World Bank (2013).

2. This was the case: Chrétien (2003). Lines blurred: Gourevitch (1998). Throughout, we have opted to use "ethnic," "ethnicity," or similar terms, although some might consider the structure of the Hutu-Tutsi relationship to resemble a caste system. Political scientist Donald Horowitz (2000, pp. 22-24) distinguishes between "ranked" (i.e., horizontally-cleaved) and "unranked (i.e., vertically-cleaved) ethnic systems. Ranked ethnic systems are those in which ethnicity coincides with socioeconomic status; unranked are those in which it does not. In India, for instance, the caste system constitutes a ranked ethnic system according to the Horowitz definition (at least in its stronger, rural manifestations). A priori, it would appear that ranked ethnic systems are more likely to exhibit high levels of horizontal (i.e., "inter-group") inequality, which can be a risk factor of violent conflict (Cramer, 2003, 2005; Østby, 2007; Tadjoeddin and Chowdhury, 2009). By using the term "ethnic," the authors in no way intend to conceal any real or perceived socioeconomic injustices under the cloak of ethnic differences.

3. Hardening of ethnic lines: Chrétien (2003). Perishing in droves: Easterly and Levine (2003). Were made to work the land: Chrétien (2003).

4. At all costs: Lemarchand, (2004). Quote: Lemarchand (2004, p. 321). On this paragraph, also see Chrétien (2003) and Greenland (1976).

5. Coup caught world attention: Chrétien (2003); Lemarchand (2004). Constitution/election 1992/1993: Dravis (2000, pp. 188-194).

6. Capturing 65 seats: Dravis (2000). Top-income earners: Easterly and Levine (2003).

7. Quote "war of massacres": Chrétien (2003, p. 346). 300,000 lives; one-sixth: Hoeffler (2008). Quote "... without peace": Nkurunziza and Ngaruko (2008). Per capita GDP: Basdevant (2009). Forty years earlier: Easterly and Levine (2003). Improved per capita GDP by 2012: World Bank (2013). Underperforming: Basdevant (2009); Nkurunziz and Ngaruko (2008). Lagged behind: Basdevant (2009).

8. Conflict trap: Collier, et al. (2003). The UN has pressed: UNSC (2010). Journalistic: Bonnard (2010).

9. More than one-in-six: Huggins (2009). Refugees from DR Congo: Hoeffler (2008). Malkki: Malkki (1995).

10. Land code (land abandoned for 30 years): Theron (2009).

11. Cramer: Cramer (2005). Linear: Muller, Selgison, Fu (1989); Nafziger and Auvinen (2002). U-shaped: Hirschman (1981). Inverted U-shaped: For instance, Nagel (1974). Crosscountry panel evidence: Fort and Ruben (2006).

12. Empirically linked: Bundervoet (2009). Rainfall and rebel recruitment: Nillesen and Verwimp (2009). Inability to procure productive land: André and Platteau (1998). Population density and land access: Verpoorten (2012). McDoom: McDoom (2013). Killing of the wealthier: Bundervoet (2009); André and Platteau (1998).

13. Cognitive dissonance in social psychology: Festinger (1985) [1957]. In economics: Akerlof and Dickens (1982); Schlict (1984).

14. Arcand and Fafchamps (2012); Barr, Dekker, and Fafchamps (2010); Blumenstock, Eagle, and Fafchamps (2011); Fafchamps and Gubert (2007).

15. See Bonnard (2010). 
16. Focus on gains: IFAD (2011). Tanzania's "irregular migrants": IRIN (2013).

\section{References}

Akerlof, G.A. and W.T. Dickens. 1982. "The Economic Consequences of Cognitive Dissonance." American Economic Review. Vol. 72, No. 3, pp. 307-319.

André, C. and J.-P. Platteau. 1998. "Land Relations Under Unbearable Stress: Rwanda Caught in the Malthusian Trap." Journal of Economic Behavior and Organization. Vol. 34, No. 1, pp. 1-47. http://dx.doi.org/10.1016/S0167-2681(97)00045-0

Arcand, J.-L. and M. Fafchamps. 2012. "Matching in Community-Based Organizations." Journal of Development Economics. Vol. 98, No. 2, pp. 203-219. http://dx.doi.org/10.1016/j.jdeveco.2011.07.002

Barr, A., M. Dekker, and M. Fafchamps. 2010. "The Formation of Community-Based Organizations in Sub-Saharan Africa: An Analysis of a Quasi-Experiment." Leiden, NL: African Studies Centre, Leiden University.

Basdevant, O. 2009. "How Can Burundi Raise Its Growth Rate? The Impact of Civil Conflicts and State Intervention on Burundi's Growth Performance." IMF Working Papers. Washington, D.C.: International Monetary Fund.

Blumenstock, J., N. Eagle, and M. Fafchamps. 2011. "Risk and Reciprocity Over the Mobile Phone Network: Evidence from Rwanda." University of Oxford. Department of Economics. Center for the Study of African Economies. Working Paper WPS/2011-19.

Bonnard, J. 2010. "La Bataille de la terre.” Paris: France 24. http://www.france24.com/fr/20110107-reporters-burundi -bataille-terre-agriculture-paysans-conflits-demographie-t ribunaux-rapatries-loi-fonciere-reforme/ [accessed 7 May 2014].

Bundervoet, T. 2009. "Livestock, Land and Political Power: The 1993 Killings in Burundi." Journal of Peace Research. Vol. 46, No. 3, pp. 357-376. http://dx.doi.org/10.1177/0022343309102657

Chrétien, J.-P. 2003. The Great Lakes Region of Africa: Two Thousand Years of History. New York: Zone Books.

Collier, P., et al. 2003. Breaking the Conflict Trap: Civil War and Development. Washington, D.C.: World Bank.

Cramer, C. 2003. "Does Inequality Cause Conflict?” Journal of International Development. Vol. 15, No. 4, pp. 397-412. http://dx.doi.org/10.1002/jid.992

Cramer, C. 2005. Inequality and Conflict: A Review of an Age-Old Concern. Identities, Conflict and Cohesion Programme Paper No. 11. Geneva: United Nations Research Institute for Social Development.

Dravis, M. 2000. Burundi in the 1990s: From Democratization to Communal War, in Peoples Versus States: Minorities at Risk in the New Century. United States Institute of Peace Press: Washington, D.C.

Easterly, W. and R. Levine. 2003. "Tropics, Germs, and Crops: The Role of Endowments in Economic Development." Journal of Monetary Economics. Vol. 50, No. 1, pp. 3-39.
http://dx.doi.org/10.1016/S0304-3932(02)00200-3

Fafchamps, M. and F. Gubert. 2007. "The Formation of Risk Sharing Networks." Journal of Development Economics. Vol. 83, No. 2, pp. 326-350.

http://dx.doi.org/10.1016/j.jdeveco.2006.05.005

Festinger, L. 1985 [1957]. A Theory of Cognitive Dissonance. Stanford, CA: Stanford University Press.

Fort, R. and R. Ruben. 2006. "Land Inequality and Economic Growth: A Dynamic Panel Data Approach." Paper presented at the 2006 Annual Meeting of the International Association of Agricultural Economists. 12-18 August 2006. Gold Coast, Queensland, Australia. http://purl.umn.edu/25582 [accessed 7 May 2014].

Gourevitch, P. 1998. We Wish to Inform You that Tomorrow We Will Be Killed With Our Families: Stories from Rwanda. 1998, New York: Picador.

Greenland, J. 1976. "Ethnic Discrimination in Rwanda and Burundi," pp. 97-133 in W.A. Veenhoven, ed. Case Studies on Human Rights and Fundamental Freedoms: A World Survey. Martinus Nijhoff: The Hague.

Hirschman, A.O. 1981. "The Changing Tolerance for Income Inequality in the Course of Economic Development," in A.O. Hirschman. Essays in Trespassing: Economics to Politics and Beyond. Cambridge, UK: Cambridge University Press.

Hoeffler, A. 2008. "Dealing with the Consequences of Violent Conflicts in Africa: Background Paper for the African Development Bank Report." Oxford, UK: Center for the Study of African Economies.

Horowitz, D. 2000. Ethnic Groups in Conflict. Berkeley, CA: The University of California Press.

Huggins, C. 2009. "Peacekeeping and HLP Rights in the Great Lakes Region of Africa: Burundi, Rwanda and DR Congo," pp. 179-219, in S. Leckie, ed. Housing, Land, and Property Rights in Post-Conflict United Nations and Other Peace Operations: A Comparative Survey and Proposal for Reform. Cambridge, UK: Cambridge University Press.

[IFAD] International Fund for Agricultural Development. 2011. "Agricultural Cooperatives are Key to Reduce Hunger and Poverty." Press release. 27 September 2013. http://www.ifad.org/media/press/2011/76.htm [accessed 7 May 2014].

IRIN. 2013. "Humanitarian crisis looms for migrants expelled from Tanzania." IRIN News. 19 September 2013. http:/www.irinnews.org/report/98789/humanitarian-crisi s-looms-for-migrants-expelled-by-tanzania [accessed 23 April 2014].

Lemarchand, R. 2004. "The Burundi Genocide," pp. 321-337 in S. Totten, W.S. Parsons, and I.W. Charny, eds. Century of Genocide: Critical Essays and Eyewitness Accounts. 2nd edition. New York: Routledge.

Malkki, L.H. 1995. Purity and Exile: Violence, Memory, and National Cosmology among Hutu Refugees in Tanzania. Chicago, IL: The University of Chicago Press.

McDoom, O. 2013. "Who Killed in Rwanda's Genocide? Micro-Space, Social Influence, and Individual Participation

The Economics of Peace and Security Journal — ISSN 1749-852X — http://www.epsjournal.org.uk (C) EPS Publishing, 2014. All rights reserved. For permissions, email: ManagingEditor@epsjournal.org.uk 
in Intergroup Violence." Journal of Peace Research. Vol. 50, No. 4, pp. 453-467. http://dx.doi.org/10.1177/0022343313478958

Muller, E.N., M.A. Seligson, and H. Fu. 1989. "Land Inequality and Political Violence." American Political Science Review. Vol. 83, No. 2, pp. 425-452. http://dx.doi.org/10.2307/1962407

Nafziger, E.W. and J. Auvinen. 2002. "Economic Development, Inequality, War, and State Violence." World Development. Vol. 30, No. 2, pp. 153-163. http://dx.doi.org/10.1016/S0305-750X(01)00108-5

Nagel, J. 1974. "Inequality and Discontent: A Non-linear Hypothesis." World Politics. Vol. 26, No. 4, pp. 453-472. http://dx.doi.org/10.2307/2010097

Nillesen, E. and P. Verwimp. 2009. "Grievance, Commodity Prices and Rainfall: A Village-level Analysis of Rebel Recruitment in Burundi." Brighton, UK: MICROCON.

Nkurunziza, J.D. and F. Ngaruko. 2008. "Why Has Burundi Grown so Slowly? The Political Economy of Redistribution," pp. 51-85 in B.J. Ndulum, S. O'Connell, J.P. Azam, R.H. Bates, A.K. Fosu, J.W. Gunning, and D. Njinkeu, eds. The Political Economy of Economic Growth in Africa, 1960-2000: Country Case Studies. Vol. 2. Cambridge, UK: Cambridge University Press.

Østby, G. 2007. "Horizontal Inequalities, Political Environment, and Civil Conflict: Evidence from 55 Developing Countries, 1986-2003.” World Bank Policy Research Working Paper. Washington, D.C.: World Bank.

Schlict, E. 1984. Cognitive Dissonance in Economics. Berlin: Duncker \& Humblot.

Tadjoeddin, Z.M. and A. Chowdhury. 2009. "Socioeconomic Perspectives on Violent Conflict in Indonesia." The Economics of Peace and Security Journal. Vol. 4, No. 1, pp. 39-47.

Theron, J. 2009. "Resolving Land Disputes in Burundi." Conflict Trends. Vol. 1, pp. 3-10.

[UNSC] United Nations Security Council. 2010. UNSC Resolution 1959. UNSC: New York.

World Bank. 2013. World Development Indicators. Washington, D.C.: World Bank.

Verpoorten, M. 2012. "Leave None to Claim the Land: A Malthusian Catastrophe in Rwanda?" Journal of Peace Research. Vol. 49, No. 4, pp. 547-563.

http://dx.doi.org/10.1177/0022343312437773

The Economics of Peace and Security Journal — ISSN 1749-852X — http://www.epsjournal.org.uk C EPS Publishing, 2014. All rights reserved. For permissions, email: ManagingEditor@epsjournal.org.uk 